\title{
Efficiency of wastewater treatment plants in removal of intestinal parasites: A review approach
}

\author{
Hajar Ziaei Hezarjaribi $^{1^{\mathbb{D}}}$, Zabihollah Yousefi $^{2^{*}}{ }^{\mathbb{D}}$, Bahman Rahimi Esboei $^{{ }^{(\mathbb{D}}}$ \\ ${ }^{1}$ Department of Medical Parasitology and Mycology in School of Medicine and Toxoplasma Research Center (INRCT), Mazandaran \\ University of Medical Sciences, Sari, Iran \\ ${ }^{2}$ Department of Environmental Health, Mazandaran University of Medical Sciences, Sari, Iran \\ ${ }^{3}$ Department of Parasitology and Mycology, School of Medicine, Tonekabon Branch, Islamic Azad University, Tonekabon, Iran
}

\begin{abstract}
Background: Wastewater treatment plants (WWTPs) in urban areas, are potentially one of the causes of the spread and entry of parasitic pathogens into the environment and water resources. Numerous studies have been conducted on the presence of parasitic agents in the entry and effluent of WWTPs in different countries. This study was conducted to review the parasite prevalence in different WWTPs and assess their removal efficiency.

Methods: ScienceDirect, Scopus, Web of Science, and PubMed databases and other sites with the ability to receive a full-text related articles, were reviewed. Various keywords such as parasites, wastewater, effluent, treatment efficiency, protozoan cysts, parasitic eggs, and similar keywords were used to search articles published from 2005 to 2019. After screening the titles and abstracts of articles, 26 articles were reviewed in this study.

Results: Giardia spp, Cryptosporidium spp, Entamoeba spp, Blastocystis spp, Toxocara spp, Trichostrongylus spp, A. lumbricoides, and Hymenolepis are the most prevalent parasites. Studies show that parasitic egg hatching rates are up to $5 \%$, in aerated lagoons, up to $99.9 \%$, in activated sludge, and up to $5 \%$, in ponds due to high retention time and downstream artificial reefs.

Conclusion: Studies show that due to the current state of treatment plants and adverse operating and maintenance conditions, it is not possible to completely remove parasitic pathogens from these systems, therefore, it should be considered by regulatory authorities and the systems need to be improved for better performance of treatment plants and optimizing them, and training of users should also be improved. This review indicated that the types of natural constructed wetland in Kermanshah (Iran) and activated sludge of wastewater treatment processes in Iran and Brazil are most effective in removal of intestinal parasites.

Keywords: Waste water, Treatment, Parasites, Efficiency

Citation: Ziaei Hezarjaribi H, Yousefi Z, Rahimi Esboei B. Efficiency of wastewater treatment plants in removal of intestinal parasites: A review approach. Environmental Health Engineering and Management Journal 2020; 7(3): 171-181. doi: 10.34172/EHEM.2020.20.
\end{abstract}

Article History:

Received: 24 April 2020

Accepted: 15 July 2020

ePublished: 23 August 2020

\section{Introduction}

Parasitic infections are among the most important sources of pollution in nature which can be considered as a public health index (1). Traditionally, parasitic infections have been a health problem in raw food and drinking water so that parasitic contamination and its removal have always been one of the concerns of health practitioners and there are many studies conducted to find a method to eliminate it (2). Drinking water is the most important part of food for humans and animals and its contamination is vitally important (3). Drinking water for communities, including potable water, is derived from a variety of sources, including wastewater composed of freshwater higher than
99.9\% and impurity less than $0.1 \%$, which can be one of the most important sources of water after treatment $(4,5)$. The reuse of treated domestic wastewater as a valuable source of water for various uses, including agriculture and green space irrigation, is one of the most important purposes of wastewater treatment and conservation of resources, especially in low-water areas $(6,7)$. Wastewater reuse, especially in the agricultural sector, has many benefits, including the benefits from effluent sales, the reduction of dust through spraying, the use of nutrients such as phosphorus and nitrogen in the wastewater (8). The general benefits of wastewater reuse include agricultural irrigation (commercial crops and plants, etc) (9), landscape 
irrigation (recreation areas, playgrounds, street green spaces, urban green belts, golf courses, cemeteries, and residential areas), water recycling in the industry (cooling water, boiler feed water, industrial consumable water and construction consumable water, groundwater recharge (ground sealing, saline containment, and groundwater recharge), recreational or environmental applications (lakes and wetlands, wetland remediation, increased river water flow, fisheries, etc), non-food applications (fire, air conditioning, toilet flushing, washing the pavements and sidewalks, etc), water required for storage tanks for drinking water supply and water supply network, water supply of heating networks and air conditioning systems, water supply of the secondary water distribution networks (separate from drinking water) and so on (10-12). Thereby, reducing the use of chemical fertilizers and reducing costs and consumption of freshwater as primary sources are the positive effects of wastewater reuse projects as secondary sources, environmental protection and improvement of its quality and beauty as public resources. The quality of the used wastewater and particularly microbial infections compared with national standards and international guidelines are of great importance in these fields (13-15). Today, there are many problems related to environmental pollution by various types of effluents and sewage. Pollution of water resources such as drinking water wells by various parasites caused by different sewage and effluents of various inefficient treatment plants, negative effects of effluents on the river water quality, and deterioration of water quality index, are the main problems of communities (16-18).

Poor progress in the construction of wastewater treatment plants (WWTPs) in underdeveloped and developing countries to cover the full establishment of all municipal wastewater and the lack of development of wastewater treatment for small communities and, consequently, the discharge of dispersed wastewater or septages into the environment and other cases, causes the spread of parasitic diseases in society. Poor management and operation of existing treatment plants due to lack of attention to environmental monitoring systems and healthcare providers and environmental health is a contributing factor to this unfavorable environmental condition $(18,19)$.

In wastewater reuse, if the microbial quality of the effluent and its health aspects are not addressed, it will pose a serious risk to human health and the environment. This will be even more important when the wastewater is used for irrigation of public lands and food products, including fruits and vegetables $(6,20)$. To remove the pollutants present in the wastewater, including organic matter and pathogens, the wastewater must be treated. There are various purification processes including biological treatment such as activated sludge modifications, stabilization ponds, artificial wetlands, lagoon aeration, and trickling filters (20-25) and physicochemical treatment (coagulation, oxidation, ozonation, adsorption membrane technology, and other advanced treatment). The mechanism of parasitic egg removal during sewage treatment processes is different. The main mechanisms are sedimentation, filtration, adsorption, entrapment in activated sludge flocs, and inactivation due to adverse environmental conditions (26-29). In this review, studies conducted on parasitic pollution in WWTPs and the effects of treatment process on parasites and parasitic pollutants removal were investigated.

\section{Materials and Methods}

The articles reviewed in this study include an original research papers and cross-sectional descriptive studies on the presence of parasites and parasitic pollutants in untreated wastewater and effluent from treatment plants, published in Iranian or foreign journals. All full-text articles that were available and published from 2005 to 2019 were included in this review. Studies that did not meet these criteria were excluded from the study. Therefore, the articles of the congresses and the abstracts of the articles were not examined at all. First, the format of extracting data from articles was determined based on the discussion and agreement between researchers and authors of the articles. After extracting the articles data, they were reviewed several times by three reviewers and the differences were determined after discussion and agreement. The extracted data include the type of WWTPs (industrial, hospital, urban, etc). The study group included a variety of urban and domestic wastewater, hospital, agricultural, and industrial wastewater, and a variety of treatment plants and their performance in eliminating pollution and the presence of parasitic agents in effluents. The parasite species, whether protozoa or worms, were reported to be pathogenic or non-pathogenic. The concentration and density of parasitic pollutants in raw sewage and various types of WWTPs and their prevalence in the studied communities were investigated. Different valid databases such as ScienceDirect, Scopus, Web of Science, PubMed, and other sites with the ability to receive a full-text related articles were reviewed. Various keywords such as parasites wastewater, effluent, treatment efficiency, protozoan cysts, parasitic eggs, and similar keywords were used to search. By searching the above-mentioned key words, 3017 papers were found, and based on title and abstracts, 2939 papers were excluded, and finally, 26 sources were reviewed in this study.

\section{Results}

Prevalence of parasitic infections in water treatment system

Based on the collected data, nine studies have been conducted to investigate the prevalence of parasitic infections in different treatment plants (Table 1). The most prevalent infections include protozoan cyst infections such as Giardia spp and Cryptosporidium 


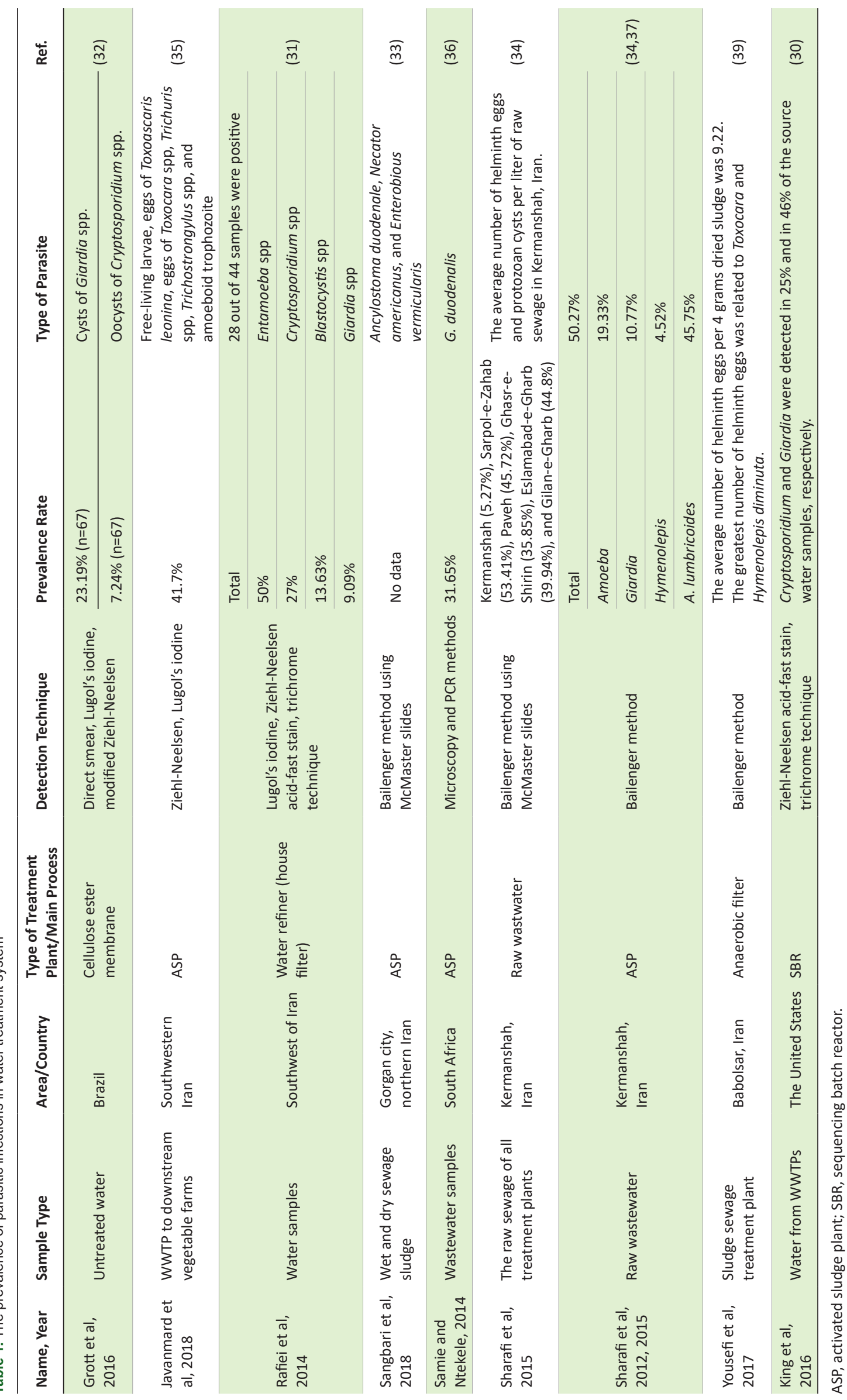


spp, amoeboid trophozoites such as Entamoeba spp, Blastocystis spp, and helminthic infections such as Toxocara spp, Trichostrongylus spp, Ascaris lumbricoides, and Hymenolepis. The prevalence of G. Lamblia infections were reported 9.09 to $46.0 \%$ in Southwest of Iran and the United States, respectively $(30,31)$. The prevalence of Cryptosporidium spp. in raw wastewater was reported 7.2427\% (30-32). The prevalence of Entamoeba spp, Ascaris, and $H$. nana was 50,45.75, and $4.52 \%$, respectively (Table 1) $(33,34)$. The removal efficacy of parasites in WWTPs is presented in Table 2.

\section{Discussion}

In this study, the studies conducted on the status of parasitic contamination in the wastewater of treatment plants, as well as the effect of treatment plants on removal of these factors, were reviewed. Due to climate changes, drought, and urban expansion, as well as the increasing need for water for drinking, irrigation, agricultural and industrial uses, water reuse is one of the most important subjects in the world $(7,14,50,66)$. For recycling wastewater, examining sewage pollution and the role of water treatment plants in removing these pollutants is of great importance. Parasitic infections are one of the most important causes of water contamination and even drinking water contamination which can have irreparable risks to human health if not eliminated. This will be even more important when the wastewater is used for irrigation of public green space and food products including poultry and vegetables $(35,67,68)$. In order to remove pollutants present in wastewater, including organic matter and pathogens, wastewater should be treated. There are various purification processes including activated sludge, stabilization ponds, artificial wetlands, aerated lagoon, and drainage filters (7,38,42,48,69-71). Different mechanisms are used for removal of parasite egg during sewage treatment processes. The main mechanisms are sedimentation, filtration, plant root uptake, entrapment in activated sludge flocs, and inactivation due to adverse environmental conditions (7,34,37,44,46,62,70,72-74). In recent years, many studies have been conducted to investigate parasitic contamination in water resources and the results have shown that many of these sources are contaminated with parasitic infections. Protozoan such as G. lamblia, Cryptosporidium spp, Entamoeba spp, Blastocystis, various species of free-living amoebae and worms such as Trichostrongylus spp, A. lumbricoides, Enterobius vermicularis, Trichuris trichiura, and Hymenolepis spp. are the most commonly reported parasites $(4,32,40,52,57)$. Javanmard et al examined the contamination of WWTPs in southwestern Iran and found that $41.7 \%$ of the municipal WWTPs were contaminated with parasites such as Toxocara, Trichuris, Trichostrongylus, and various species of amoeba (35). In another study, Sharafi et al examined the treatment plants in different cities of Kermanshah province and showed that all municipal WWTPs in this province were infected with parasitic infections $(34,37)$.

In Brazil and South Africa, 30.43\% and 31.65\% of wastewater was respectively infected with parasitic infections $(36,44,75,76)$. One criterion for checking the quality of the WWTPs is the number of parasitic eggs per liter of wastewater, which varies across countries. Different rates have been reported in developing countries such as Brazil (206-166), Morocco (840-214), Jordan (300), Pakistan (144), Russia ( $\geq 2000)$, and Ukraine (60). In advanced countries such as USA, France, and Germany, it was reported 1-8, 9-10, and less than 40 per liter, respectively $(40,41,43,70,75)$. Based on the results of the studies, it can be concluded that the sewage systems of large and industrial cities are less polluted than those of small cities, which could be due to the production of industrial wastewater (without parasitic pollution) in these cities. Another factor that is very important is the use of more advanced systems in larger cities, as well as more and more strict control in larger cities. The results of these studies show that parasitic infection is one of the inevitable factors of urban and rural wastewater that its removal is necessary for reuse of these resources. To eliminate infections, treatment plants use a variety of techniques. In this review study, studies conducted on the role of treatment plants in removing parasitic infections were investigated. According to the results, 29 studies have been conducted with the title of treatment plants in the elimination of parasitic pollutions from 2008 to 2019 . Among all treatment plants, 8 treatment plants had 100\% efficacy in removing worm infections and 9 treatment plants had $100 \%$ efficacy in removing protozoa. Also, 5 treatment systems out of 29 systems (17.24\%), had 100\% efficacy in removing worms and protozoa. While the results of recent studies have shown that about $82.75 \%$ of treatment plants had not $100 \%$ efficiency in removing worms and protozoa $(14,29,43,44,51,53,55-57,60,61,72)$. Overall, helminth infections, including parasitic eggs and larvae, are more easily removed by the treatment systems compared to the protozoans. The main protozoa species include Giardia, Cryptosporidium, and Acanthamoeba, which are not completely (100\%) eliminated $(42,56,77,78)$. Since retreated wastewater will be reused and given the potential exposure of humans to these sources, it can be an important factor in causing infections in humans.

Diarrhea, abdominal pain, bloating, and irritable bowel syndrome are clinical signs of G. lamblia, and diarrhea, nausea, vomiting, abdominal cramps, and fever are symptoms of Cryptosporidium that may even cause death in people with immunodeficiency. Acanthamoeba develops granulomatosis, amoebic encephalitis, and ocular keratitis in humans. Due to the complications of parasitic diseases, inadequate treatment and reuse of these resources can have irreparable consequences for society. Studies show that parasitic egg hatching rates are up to $5 \%$, in aerated lagoons, up to $99.9 \%$, in actived sludge, 


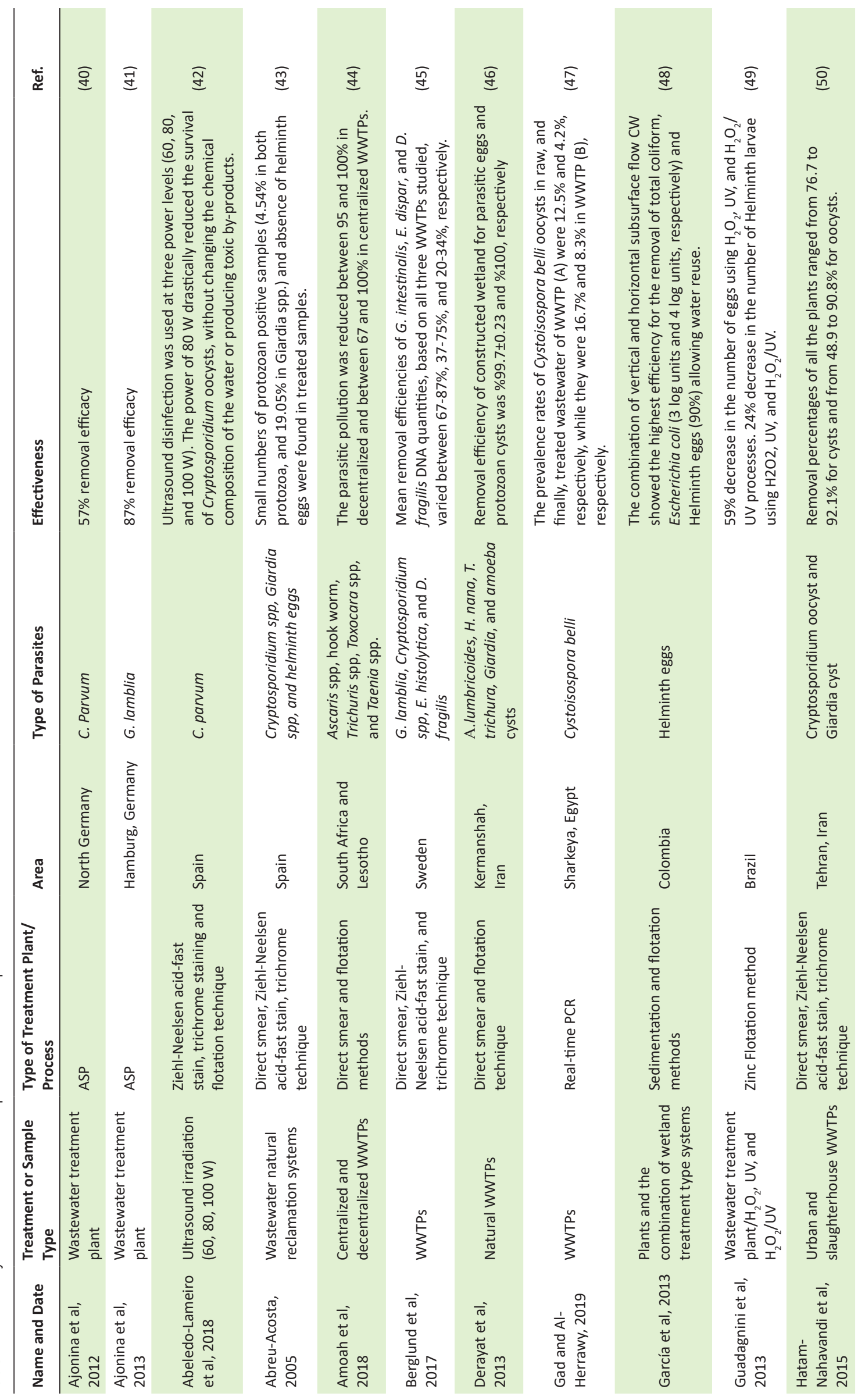




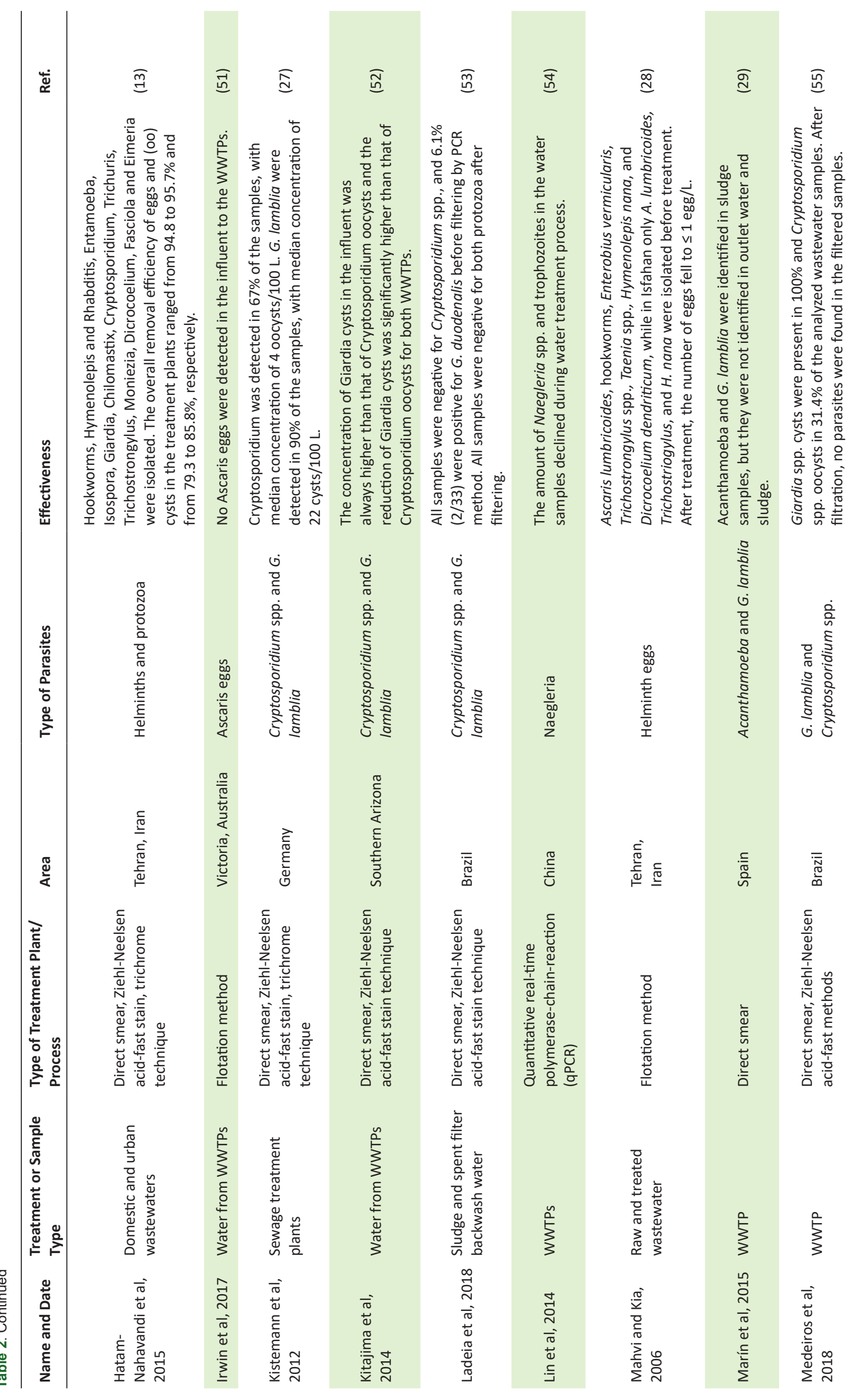




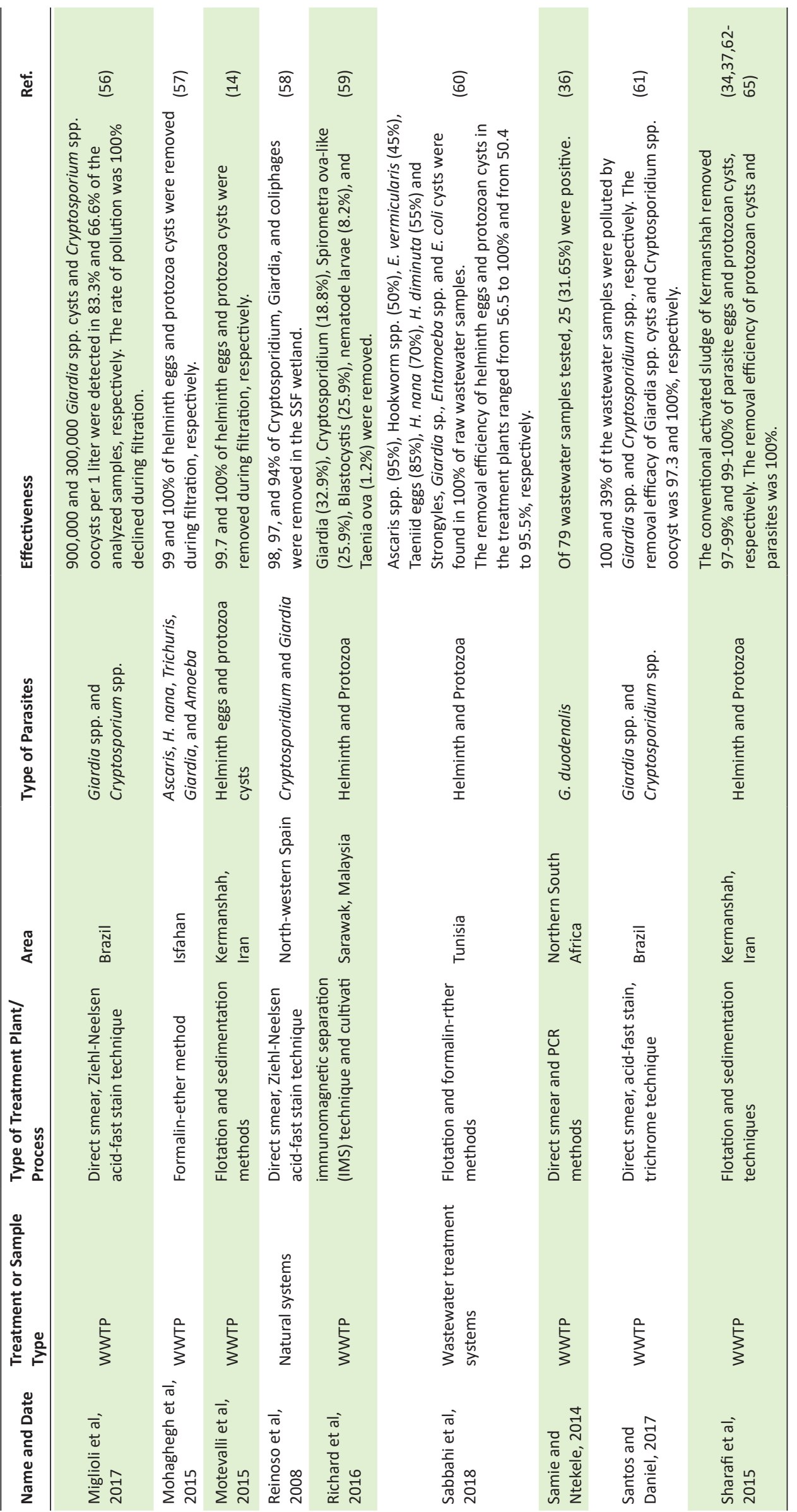


and up to $5 \%$, in ponds due to high retention time and downstream artificial reefs. The access level of 5\% in each of these processes is a function of the characteristics of the incoming wastewater and the design criteria of the WWTP, which can be very unstable. Also, the present review show that the type of the natural constructed wetland in Kermanshah (Iran) and activated sludge processes in Iran and Brazil had the highest efficiency in removal of intestinal parasites. Also, units of aeration basin and secondary clarifier in municipal treatment plants have more roles in removal of intestinal parasites.

\section{Conclusion}

According to the results of the studies reviewed, treatment plants are not capable of complete removal of parasitic contaminants using existing systems and need to be addressed by health authorities. The present review showed that the natural constructed wetland in Kermanshah (Iran) and activated sludge of wastewater treatment processes in Iran and Brazil had the highest efficiency in removal of intestinal parasites. It is suggested that other treatment plants also need to be examined for removal of parasitic and other microbial and viral infections. It is also essential to investigate the efficiency of wastewater treatment systems in removal of parasitic infections in different countries using uniform tests and identify the best process to use in the future.

\section{Acknowledgements}

The authors would like to express their gratitude and appreciation to the Vice-Chancellor for Research and Technology of Mazandaran University of Medical Sciences, for supporting the study.

\section{Ethical issues}

In this article, the authors considered all the ethical points in collecting data and confidently state that this information has not been previously published in any publication or book. This article was extracted from a plan approved by the Department of Environmental Health Engineering, School of Health, Mazandaran University of Medical Sciences (Approval code: 8033) and the ethical code of the Ethics Committee will be IR.mazums. rec.1399.8033.

\section{Competing interests}

The authors declare that there is no conflicts of interests in this study.

\section{Authors' contributions}

All authors have contributed to the collection of articles, reviewing articles, writing and editing the article and all items related to the article.

\section{References}

1. Savioli L, Bundy D, Tomkins A. Intestinal parasitic infections: a soluble public health problem. Trans R Soc Trop Med Hyg 1992; 86(4): 353-4. doi: 10.1016/00359203(92)90215-x.

2. Ottoson J, Hansen A, Björlenius B, Norder H, Stenström TA. Removal of viruses, parasitic protozoa and microbial indicators in conventional and membrane processes in a wastewater pilot plant. Water Res 2006; 40(7): 1449-57. doi: 10.1016/j.watres.2006.01.039.

3. Tobiason JE, Bazilio A, Goodwill J, Mai X, Nguyen C. Manganese removal from drinking water sources. Curr Pollut Rep 2016; 2(3): 168-77. doi: 10.1007/s40726-0160036-2.

4. Leelayoova S, Siripattanapipong S, Thathaisong U, Naaglor T, Taamasri P, Piyaraj P, et al. Drinking water: a possible source of Blastocystis spp. subtype 1 infection in schoolchildren of a rural community in central Thailand. Am J Trop Med Hyg 2008; 79(3): 401-6.

5. Osmani M, Mali S, Hoxha B, Bekteshi L, Karamelo P, Gega $\mathrm{N}$. Drinking water quality determination through the water pollution indicators, Elbasan district. Thalassia Salentina 2019; 41: 3-10. doi: 10.1285/i15910725v41p3.

6. Martínez-Huitle CA, Panizza M. Electrochemical oxidation of organic pollutants for wastewater treatment. Curr Opin Electrochem 2018; 11: 62-71. doi: 10.1016/j. coelec.2018.07.010.

7. Liberti L, Notarnicola M, Petruzzelli D. Advanced treatment for municipal wastewater reuse in agriculture. UV disinfection: parasite removal and by-product formation. Desalination 2003; 152(1-3): 315-24. doi: 10.1016/S00119164(02)01079-2.

8. De Sanctis M, Del Moro G, Chimienti S, Ritelli P, Levantesi C, Di Iaconi C. Removal of pollutants and pathogens by a simplified treatment scheme for municipal wastewater reuse in agriculture. Sci Total Environ 2017; 580: 17-25. doi: 10.1016/j.scitotenv.2016.12.002.

9. Jaramillo MF, Restrepo I. Wastewater reuse in agriculture: a review about its limitations and benefits. Sustainability 2017; 9(10): 1734. doi: 10.3390/su9101734.

10. Corzo B, de la Torre T, Sans C, Escorihuela R, Navea S, Malfeito JJ. Long-term evaluation of a forward osmosisnanofiltration demonstration plant for wastewater reuse in agriculture. Chem Eng J 2018; 338: 383-91. doi: 10.1016/j. cej.2018.01.042.

11. Tran QK, Schwabe KA, Jassby D. Wastewater reuse for agriculture: development of a regional water reuse decisionsupport Model (RWRM) for cost-effective irrigation sources. Environ Sci Technol 2016; 50(17): 9390-9.

12. Nguyen-Viet $H$, Pham-Duc P, Petterson S, Medema G. Wastewater reuse in agriculture and health risk in Vietnam. In Global Water Pathogen Project. Michigan State University. https://doi.org/10.14321/waterpathogens.70.

13. Hatam-Nahavandi K, Mohebali M, Mahvi AH, Keshavarz H, Khanaliha K, Tarighi F, et al. Evaluation of Cryptosporidium oocyst and Giardia cyst removal efficiency from urban and slaughterhouse wastewater treatment plants and assessment of cyst viability in wastewater effluent samples from Tehran, Iran. Journal of Water Reuse and Desalination 2015; 5(3): 372-90. doi: 10.2166/wrd.2015.108.

14. Motevalli MD, Ghayebzadeh M, Arfaeinia H, Sharafi K, Hosseini Z, Sharafi H. Investigation of effluent microbial quality of wastewater treatment natural systems in term 
of parasitic contamination with the purpose of reuse for agricultural irrigation - a case study. Int Res J Appl Basic Sci 2015; 9(10): 1799-804.

15. Saeidi M, Biglari H, Baneshi MM, Narooie MR, Dargahi A, Mobini M, et al. A feasibility study of reusing the sewage of the wastewater treatment plant in Torbat-e Heydarieh. Pollut Res 2017; 36(3): 456-61.

16. Mohseni-Bandpei A, Yousefi Z. Status of water quality parameters along Haraz river. Int J Environ Res 2013; 7(4): 1029-38. doi: 10.22059/ijer.2013.687.

17. Nasirahmadi K, Yousefi Z, Tarassoli A. Zoning of water quality on Haraz river bases on national sanitation foundation water quality index. Journal of Mazandaran University of Medical Sciences 2012; 22(92): 64-71. [In Persian].

18. YousefiZ, Ziaei Hezarjaribi H, Enayati AA, Mohammadpoor RA. Parasitic contamination of wells drinking waterin Mazandaran province. Iran J Environ Health Sci Eng 2009; 6(4): 241-6.

19. Yousefi Z, Seyedi Rad M. Quantitative and qualitative study of urban septage in east of Mazandaran and administrative approaches. Journal of Mazandaran University of Medical Sciences 2013; 23(102): 61-71. [In Persian].

20. Farzadkia M, Ehrampoush MH, Sadeghi S, Kermani M, Ghaneian MT, Ghelmani SV, et al. Performance evaluation of wastewater stabilization ponds in Yazd-Iran. Environ Health Eng Manag 2014; 1(1): 7-12.

21. Ehrampoush MH, Hossein Shahi D, Ebrahimi A, Ghaneian MT, Lotfi MH, Ghelmani SV, et al. Evaluation of the efficiency of sub-surface constructed wetland methods in wastewater treatment in Yazd city in 2011. Tolooebehdasht 2013; 12(1): 33-43. [In Persian].

22. Emamjomeh MM, Jamali HA, Moradnia M, Mousavi S, Karimi Z. Sanitary wastewater treatment using combined anaerobic and phytoremediation systems. Journal of Mazandaran University of Medical Sciences 2016; 26(138): 140-50. [In Persian]

23. Kokkinos P, Mandilara G, Nikolaidou A, Velegraki A, Theodoratos P, Kampa D, et al. Performance of three smallscale wastewater treatment plants. A challenge for possible re use. Environ Sci Pollut Res Int 2015; 22(22): 17744-52. doi: 10.1007/s11356-015-4988-3.

24. Irandoost M, Salehi Tabriz A. The effect of municipal wastewater on soil chemical properties. Solid Earth Discuss 2017; 1-13. doi: 10.5194/se-2017-6.

25. Fahiminia M, Ansari M, Nazari S, Majidi G, Fahiminia $\mathrm{V}$, Nasseri S, et al. Survey of solid waste and wastewater separate and combined management strategies in rural areas of Iran. Iran J Health Sci 2014; 2(4): 27-35. doi: 10.18869/acadpub.jhs.2.4.27.

26. Naddafi K, Jaafarzadeh N, Mokhtari M, Zakizadeh B, Sakian MR. Effects of wastewater stabilization pond effluent on agricultural crops. Int J Environ Sci Technol 2005; 1(4): 273-7. doi: 10.1007/BF03325842.

27. Kistemann T, Rind E, Koch C, Claßen T, Lengen C, Exner $\mathrm{M}$, et al. Effect of sewage treatment plants and diffuse pollution on the occurrence of protozoal parasites in the course of a small river. Int J Hyg Environ Health 2012; 215(6): 577-83. doi: 10.1016/j.ijheh.2011.12.008.

28. Mahvi AH, Kia EB. Helminth eggs in raw and treated wastewater in the Islamic Republic of Iran. East Mediterr
Health J 2006; 12(1-2): 137-43.

29. Marín I, Goñi P, Lasheras AM, Ormad MP. Efficiency of a Spanish wastewater treatment plant for removal potentially pathogens: characterization of bacteria and protozoa along water and sludge treatment lines. Ecol Eng 2015; 74: 28-32. doi: 10.1016/j.ecoleng.2014.09.027.

30. King DN, Donohue MJ, Vesper SJ, Villegas EN, Ware MW, Vogel ME, et al. Microbial pathogens in source and treated waters from drinking water treatment plants in the United States and implications for human health. Sci Total Environ 2016; 562: 987-95. doi: 10.1016/j.scitotenv.2016.03.214.

31. Rafiei A, Rahdar M, Valipour Nourozi R. Isolation and identification of parasitic protozoa in sampled water from the southwest of Iran. Jundishapur J Health Sci 2014; 6(4): e23462. doi: $10.5812 /$ jjhs.23462.

32. Grott SC, Hartmann B, da Silva Filho HH, Franco RMB, Goulart JAG. Detection of Giardia spp. cysts and Cryptosporidium spp. oocysts in untreated water collected from treatment plants in Blumenau, Santa Catarina State, Brazil. Rev Ambient Água 2016; 11(3): 689-701. doi: 10.4136/ambi-agua.1853.

33. Sangbari N, Dadban Shahamat Y, Abbasinejat Z, Sharbatkhori M, Rostami M. Survey of parasitic contamination of sewage sludges in northern Iran. J Appl Sci Environ Manag 2018; 22(8): 1277-80. doi: 10.4314/ jasem.v22i8.21.

34. Sharafi K, Moradi M, Karami A, Khosravi T. Comparison of the efficiency of extended aeration activated sludge system and stabilization ponds in real scale in the removal of protozoan cysts and parasite ova from domestic wastewater using Bailenger method: a case study, Kermanshah, Iran. Desalin Water Treat 2015; 55(5): 1135-41. doi: 10.1080/19443994.2014.923333.

35. Javanmard E, Mirjalali H, Niyyati M, Sharifdini M, Jalilzadeh E, Seyed Tabaei SJ, et al. Small-scale risk assessment of transmission of parasites from wastewater treatment plant to downstream vegetable farms. Gastroenterol Hepatol Bed Bench 2018; 11(4): 352-8.

36. Samie A, Ntekele P. Genotypic detection and evaluation of the removal efficiency of Giardia duodenalis at municipal wastewater treatment plants in Nnorthern South Africa. Trop Biomed 2014; 31(1): 122-33.

37. Sharafi K, Fazlzadehdavil M, Pirsaheb M, Derayat J, Hazrati $\mathrm{S}$. The comparison of parasite eggs and protozoan cysts of urban raw wastewater and efficiency of various wastewater treatment systems to remove them. Ecol Eng 2012; 44: 2448. doi: 10.1016/j.ecoleng.2012.03.008.

38. Almasi A, Mohammadi M, Shokri R, Hashemi M, Bahmani N. Effect of solar light on the decrease of microbial contamination in facultative stabilization pond. J Adv Environ Health Res 2018; 6(2): 90-5. doi: 10.22102/ jaehr.2018.104707.1047.

39. Yousefi Z, Ziaei Hezarjaribi H, Mousavinasab N, Soltani A. Identifying parasites in the outlet sludge of industrial wastewater treatment plant: a case study in Babolsar, Iran 2015. Journal of Mazandaran University of Medical Sciences 2018; 27(156): 177-86. [In Persian].

40. Ajonina C, Buzie C, Ajonina IU, Basner A, Reinhardt $\mathrm{H}$, Gulyas $\mathrm{H}$, et al. Occurrence of Cryptosporidium in a wastewater treatment plant in North Germany. J Toxicol Environ Health A 2012; 75(22-23): 1351-8. doi: 
$10.1080 / 15287394.2012 .721167$.

41. Ajonina C, Buzie C, Otterpohl R. The detection of Giardia cysts in a large-scale wastewater treatment plant in Hamburg, Germany. J Toxicol Environ Health A 2013; 76(8): 509-14. doi: 10.1080/15287394.2013.785208.

42. Abeledo-Lameiro MJ, Ares-Mazás E, Goméz-Couso H. Use of ultrasound irradiation to inactivate Cryptosporidium parvum oocysts in effluents from municipal wastewater treatment plants. Ultrason Sonochem 2018; 48: 118-26. doi: 10.1016/j.ultsonch.2018.05.013.

43. Abreu-Acosta N, Lorenzo-Morales J, Leal-Guio Y, Coronado-Alvarez N, Foronda P, Alcoba-Florez J, et al. Enterocytozoon bieneusi (microsporidia) in clinical samples from immunocompetent individuals in Tenerife, Canary Islands, Spain. Trans R Soc Trop Med Hyg 2005; 99(11): 848-55. doi: 10.1016/j.trstmh.2005.05.010.

44. Amoah ID, Reddy P, Seidu R, Stenström TA. Removal of helminth eggs by centralized and decentralized wastewater treatment plants in South Africa and Lesotho: health implications for direct and indirect exposure to the effluents. Environ Sci Pollut Res Int 2018; 25(13): 12883-95. doi: 10.1007/s11356-018-1503-7.

45. Berglund B, Dienus O, Sokolova E, Berglind E, Matussek A, Pettersson T, et al. Occurrence and removal efficiency of parasitic protozoa in Swedish wastewater treatment plants. Sci Total Environ 2017; 598: 821-7. doi: 10.1016/j. scitotenv.2017.04.015.

46. Derayat J, Almasi A, Sharafi K, Meskini H. A comparison of the efficiency of natural wastewater treatment plants in removal of protozoan cysts and parasitic eggs. Water and Wastewater 2013; 24(2): 11-8. [In Persian].

47. Gad MA, Al-Herrawy AZ. Prevalence of Cystoisospora belli in wastewater treatment plants in Sharkeya, Egypt. Asian J Water Environ Pollut 2019; 16(1): 9-13. doi: 10.3233/ ajw190002.

48. García JA, Paredes D, Cubillos JA. Effect of plants and the combination of wetland treatment type systems on pathogen removal in tropical climate conditions. Ecol Eng 2013; 58: 57-62. doi: 10.1016/j.ecoleng.2013.06.010.

49. Guadagnini RA, dos Santos LU, Franco RM, Guimarães JR. Inactivation of bacteria and helminth in wastewater treatment plant effluent using oxidation processes. Water Sci Technol 2013; 68(8): 1825-9. doi: 10.2166/wst.2013.431.

50. Hatam-Nahavandi K, Mahvi AH, Mohebali M, Keshavarz H, Mobedi I, Rezaeian M. Detection of parasitic particles in domestic and urban wastewaters and assessment of removal efficiency of treatment plants in Tehran, Iran. J Environ Health Sci Eng 2015; 13: 4. doi: 10.1186/s40201015-0155-5.

51. Irwin R, Surapaneni A, Smith D, Schmidt J, Rigby H, Smith SR. Verification of an alternative sludge treatment process for pathogen reduction at two wastewater treatment plants in Victoria, Australia. J Water Health 2017; 15(4): 626-37. doi: 10.2166/wh.2017.316.

52. Kitajima M, Haramoto E, Iker BC, Gerba CP. Occurrence of Cryptosporidium, Giardia, and Cyclospora in influent and effluent water at wastewater treatment plants in Arizona. Sci Total Environ 2014; 484: 129-36. doi: 10.1016/j. scitotenv.2014.03.036.

53. Ladeia WA, Martins FD, Silva CF, Freire RL. Molecular surveillance of Cryptosporidium and Giardia duodenalis in sludge and spent filter backwash water of a water treatment plant. J Water Health 2018; 16(5): 857-60. doi: 10.2166/ wh.2018.040.

54. Lin W, Yu Z, Zhang H, Thompson IP. Diversity and dynamics of microbial communities at each step of treatment plant for potable water generation. Water Res 2014; 52: 218-30. doi: 10.1016/j.watres.2013.10.071.

55. Medeiros RC, Daniel LA, de Oliveira GL, Hoffmann MT. Performance of a small-scale wastewater treatment plant for removal of pathogenic protozoa (oo)cysts and indicator microorganisms. Environ Technol 2019; 40(26): 3492-501. doi: 10.1080/09593330.2018.1480063.

56. Miglioli MG, Zuanazzi JG, da Silva JD, Franco RMB, Greinert-Goulart JA. Removal of Cryptosporidium spp. oocysts and Giardia spp. cysts at a waste water treatment plant garcia, in Blumenau, SC, Brazil. Rev Ambient Água 2017; 12(6): 1001-16. doi: 10.4136/ambi-agua.2028.

57. Mohaghegh MA, Jafari R, Ghomashlooyan M, Mirzaei F, Azami M, Falahati M, et al. Soil contamination with oocysts of Cryptosporidium spp. in Isfahan, Central Iran. Int J Enteric Pathog 2015; 3(3): e29105. doi: 10.17795/ijep29105.

58. Reinoso R, Torres LA, Bécares E. Efficiency of natural systems for removal of bacteria and pathogenic parasites from wastewater. Sci Total Environ 2008; 395(2-3): 80-6. doi: $10.1016 /$ j.scitotenv.2008.02.039.

59. Richard RL, Ithoi I, Abd Majid MA, Wan Sulaiman WY, Tan TC, Nissapatorn V, et al. Monitoring of waterborne parasites in two drinking water treatment plants: a study in Sarawak, Malaysia. Int J Environ Res Public Health 2016; 13(7). doi: 10.3390/ijerph13070641.

60. Sabbahi S, Trad M, Ben Ayed L, Marzougui N. Occurrence of intestinal parasites in sewage samples and efficiency of wastewater treatment systems in Tunisia. Water Qual Res J 2018; 53(2): 86-101. doi: 10.2166/wqri.2018.033.

61. Santos PR, Daniel LA. Occurrence and removal of Giardia spp.cysts and Cryptosporidium spp. oocysts from a municipal wastewater treatment plant in Brazil. Environ Technol 2017; 38(10): 1245-54. doi: 10.1080/09593330.2016.1223175.

62. Sharafi K, Drayat J, Khodadadi T, Asadi F, Poureshg Y. The efficiency comparison of constructed wetland and conventional activated sludge on removal of cysts and parasitic eggs-case study: Ghasr-e-Shirin and Kermanshah wastewater treatment plants. Journal of Health 2011; 2(3): 7-13. [In Persian].

63. Sharafi K, Pirsaheb M, Khosravi T, Dargahi A, Moradi M, Savadpour MT. Fluctuation of organic substances, solids, protozoan cysts, and parasite egg at different units of a wastewater integrated stabilization pond (full scale treatment plant): a case study, Iran. Desalin Water Treat 2016; 57(11): 4913-9. doi: 10.1080/19443994.2014.997294.

64. Sharafi K, Fazlzadeh Davil M, Heidari M, Almasi A, Taheri H. Comparison of conventional activated sludge system and stabilization pond in removal of chemical and biological parameters. Int J Environ Health Eng 2012; 1: 38. doi: $10.4103 / 2277-9183.102360$.

65. Sharafi K, Fazlzadeh M, Pirsaheb M, Sharafi H, Khosravi T. Determining parasite presence in raw municipal wastewater by Bailenger method in Kermanshah, Iran. Water Qual Expo Health 2015; 7(4): 525-30. doi: 10.1007/s12403-015- 
0168-4.

66. Stott R, Jenkins T, Shabana M, May E. A survey of the microbial quality of wastewaters in Ismailia, Egypt and the implications for wastewater reuse. Water Sci Technol 1997; 35(11-12): 211-7. doi: 10.1016/S0273-1223(97)00261-8.

67. Alghobar MA, Suresha S. Growth and yield of tomato, Napier grass and sugarcane crops as influenced by wastewater irrigation in Mysore, Karnataka, India. World Research Journal of Agricultural Sciences 2016; 3(1): 69-79.

68. Razzaghi S, Khodaverdiloo H, Ghorbani Dashtaki S. Effects of long-term wastewater irrigation on soil physical properties and performance of selected infiltration models in a semi-arid region. Hydrol Sci J 2016; 61(10): 1778-90. doi: 10.1080/02626667.2015.1051981.

69. Amahmid O, Asmama S, Bouhoum K. Urban wastewater treatment in stabilization ponds: occurrence and removal of pathogens. Urban Water 2002; 4(3): 255-62. doi: 10.1016/ s1462-0758(01)00071-1.

70. Chaoua S, Boussaa S, Khadra A, Boumezzough A. Efficiency of two sewage treatment systems (activated sludge and natural lagoons) for helminth egg removal in Morocco. J Infect Public Health 2018; 11(2): 197-202. doi: 10.1016/j.jiph.2017.07.026.

71. Farzadkia M, Jafarzadeh Haghighifard N, Loueimi Asl L, Ghalambor AA. Wastewater sludge stabilization using lime a case study of west Ahwaz wastewater treatment plant. Water and Wastewater 2009; 19(4): 67-71. [In Persian].

72. Derayat J, Almasi A, Sharafi K, Meskini H, Dargahi A. The efficiency comparison of conventional activated sludge and stabilization pond systems in removal of cysts and parasitic eggs (a case study: Kermanshah and Gilangharb wastewater treatment plants). Iran J Health Environ 2011; 4(2): 181-8. [In Persian].

73. Dehghani fard E, Jonidi Jafari A, Rezae Kalantari R, Gholami M, Esrafili A. Photocatalytic removal of aniline from synthetic wastewater using $\mathrm{ZnO}$ nanoparticle under ultraviolet irradiation. Iran J Health Environ 2012; 5(2): 167-78. [In Persian].

74. Stott R, Jenkins T, Bahgat M, Shalaby I. Capacity of constructed wetlands to remove parasite eggs from wastewaters in Egypt. Water Sci Technol 1999; 40(3): 11723. doi: 10.1016/S0273-1223(99)00454-0.

75. Osaki SC, Soccol VT, Costa AO, Oliveira-Silva MB, Pereira JT, Procópio AE. Polymerase chain reaction and nestedPCR approaches for detecting Cryptosporidium in water catchments of water treatment plants in Curitiba, State of Paraná, Brazil. Rev Soc Bras Med Trop 2013; 46(3): 270-6. doi: 10.1590/0037-8682-0053-2013.

76. Cock IE, Selesho MI, Van Vuuren SF. A review of the traditional use of southern African medicinal plants for the treatment of selected parasite infections affecting humans. J Ethnopharmacol 2018; 220: 250-64. doi: 10.1016/j. jep.2018.04.001.

77. Lim YA, Wan Hafiz WI, Nissapatorn V. Reduction of Cryptosporidium and Giardia by sewage treatment processes. Trop Biomed 2007; 24(1): 95-104.

78. Xiao S, Hu S, Zhang Y, Zhao X, Pan W. Influence of sewage treatment plant effluent discharge into multipurpose river on its water quality: a quantitative health risk assessment of Cryptosporidium and Giardia. Environ Pollut 2018; 233: 797-805. doi: 10.1016/j.envpol.2017.11.010. 